Nafta-Gaz 2019, nr 6, s. 330-343 , DOI: 10.18668/NG.2019.06.04

\title{
Paleokras w utworach górnej jury podłoża zapadliska przedkarpackiego i jego znaczenie złożowe
}

\section{Paleokarst phenomena in the Upper Jurassic deposits in the Carpathian Foredeep substrate and its reserves importance}

\author{
Mariusz Miziołek, Bogdan Filar \\ Instytut Nafty i Gazu - Państwowy Instytut Badawczy
}

\begin{abstract}
STRESZCZENIE: W pracy przedstawiono wyniki badań i analiz, jakie zrealizowano w N części zapadliska przedkarpackiego, których przedmiotem były przede wszystkim skały wapienne górnej jury. Badania miały charakter ściśle analityczny i dotyczyły reinterpretacji: opisów rdzeni wiertniczych z rejonu na północ od Tarnowa, dostępnych danych wiertniczych oraz obserwacji złożowych. W sumie przeprowadzono analizę kilkudziesięciu otworów i została ona wykonana pod kątem identyfikacji w badanych otworach paleokrasu, czyli pogrążonych dużych form krasu, takich jak: leje krasowe, studnie krasowe, jaskinie, korytarze itp. Identyfikacji form krasowych dokonano na podstawie kryteriów litologicznych, cech strukturalno-teksturalnych osadów, obserwacji wiertniczo-złożowych i kryteriów geofizycznych. Przeprowadzone analizy pozwoliły według autorów na identyfikację różnych form paleokrasu w 13 otworach. Rozpoznano szereg małych i średnich form o genezie tektoniczno-krasowej, jak np. szczeliny z różnorodnym wypełnieniem ilasto-piaskowcowym w kolorach: żółtym, rdzawym, czerwonym, zielonym, czarnym, ponadto małe kawerny i kanaliki wielkości od kilku do kilkunastu milimetrów oraz druzy i kawerny wielkości od kilku do kilkunastu centymetrów z wypełnieniem lub bez. Z dużych form krasowych zidentyfikowano struktury, które mogą reprezentować: leje krasowe, studnie krasowe, jaskinie, korytarze i jamy. Wobec lakonicznego opisu rdzeni, który całkowicie pomijał istnienie form krasowych, trudno było szczegółowo zaliczyć rozpoznane struktury do konkretnych form krasowych. W kilku przypadkach identyfikację wsparto pomiarami geofizycznymi i obserwacjami wiertniczymi, te ostatnie wykazały obecność pustek krasowych przewierconych przez odwiert. Wyniki przeprowadzonych badań analitycznych potwierdziły występowanie form paleokrasowych zarówno w obrębie udokumentowanych złóż gazu i ropy, jak i poza nimi. Wobec tego została potwierdzona hipoteza, że część objętości porowej złóż występuje w postaci pustek krasowych. Obecność pustek krasowych tłumaczy niedoszacowanie pojemności porowej na wielu złożach oraz niezrozumiałe dotychczas, występujące w obrębie jednego złoża silne zróżnicowanie ciśnień złożowych. Kras w strefie złożowej może tworzyć jeden połączony system krasowy lub dwa albo więcej takich systemów niezależnych od siebie. Wielkość poszczególnych systemów krasowych może być różna. W rejonie Wyżyny Krakowsko-Wieluńskiej występuje wiele jaskiń i systemów krasowych, a objętość poszczególnych jaskiń wynosi od kilkudziesięciu metrów sześciennych do nawet 12 tys. $\mathrm{m}^{3}$, a pojedynczych komór do 4,5 tys. $\mathrm{m}^{3}$. Identyfikacja paleokrasu na złożach jurajskich będzie miała duże znaczenie dla właściwej oceny zasobów złóż, zarówno istniejących, jak i nowych, gdyż bez uwzględnienia pojemności form krasowych obliczone zasoby będą niepełne. Obecność struktur paleokrasu na złożu będzie też miała istotne znaczenie w procesie poszukiwań, wiercenia i eksploatacji złóż ropy i gazu. Przedstawiony problem jest zatem bardzo ważny i wymaga dalszych prac, badań i analiz.
\end{abstract}

Słowa kluczowe: paleokras, kras, złoża gazu i ropy, pułapki złożowe, zapadlisko przedkarpackie.

ABSTRACT: This article presents the results of research carried on Cenomanian sandstones and mainly the Upper Jurassic limestone rocks located in the north part of the Carpathian Foreland. The research was strictly analytical and focused on the reinterpretation of the drilling core descriptions and drilling data observations collected from the Tarnów area. In general, the analysis was carried out on several dozen wells and it was performed in order to identify paleokarst phenomena or deep karst formations, such as: karst, karstic wells, caves, corridors, etc. The identification of karst formations was based on lithological criteria, structural-textural sediments features, drilling observations, and geophysical criteria. The author identified the paleokarst phenomena on 13 wells. A number of small and medium-sized forms with tectonic-karst genesis were identified, such as natural channels with various clay-sandstone fillings in the following colors: yellow, rusty, red, green, and black. Channels with a few to several millimeters apart and cavities from a few to several centimeters with or without filling were observed. Large karst formations, such as karstic wells, caves, corridors and cavities

Autor do korespondencji: M. Miziołek, e-mail: mariusz.miziolek@inig.pl

Artykuł nadesłano do Redakcji 3.01.2019 r. Zatwierdzono do druku 20.05.2019 r. 
were also identified. Due to the laconic description of the cores, which completely disregarded the existence of karst forms, it was difficult to recognize karst form structures in detail; however, in several cases, identification supported by geophysical measurements and drilling observations showed the presence of karst voids in the drilled well. The results of the analytical tests confirmed the presence of paleokarst forms within the documented gas and oil fields and outside of them. Based on the analysis, the hypothesis that part of the pore volume of the oil and gas reserves is located in the karst forms was confirmed. The presence of karst voids explains the underestimation of the pore volume of many oil and gas fields and the strong variations of the well pressure during production. The karst in the deposit zone may form one combined karst system or more karst systems independent of each other. The size of individual karst systems can vary. In the area of the Krakow-Wielun Upland there are many caves and karst systems, and the volume of caves ranges from several to even $12.000 \mathrm{~m}^{3}$, with the volume of the individual chambers attaining 4.5 thousand $\mathrm{m}^{3}$. The significance of the karst forms identification for proper assessment of reserves and production resources is very important and requires further research.

Key words: paleokarst, karst, fields gas and oil, fields traps, Carpathian Foredeep.

\section{Wstęp}

Rejon zapadliska przedkarpackiego jest jednym z najzasobniejszych obszarów gazonośnych na terytorium Polski. Zdecydowana większość złóż tego rejonu związana jest z molasowymi utworami miocenu autochtonicznego, wypełniającymi zapadlisko przedkarpackie. Skałami zbiornikowymi są tu przede wszystkim piaskowce, mułowce oraz pakiety ilasto-mułowcowe formacji nadewaporatowej (Miziołek et al., 2017). Złoża w utworach klastycznych nie są jednak jedynymi złożami występującymi na obszarze zapadliska przedkarpackiego. Akumulacje węglowodorów odkryto również w podłożu utworów miocenu, a mianowicie w skałach mezozoicznych górnej jury i górnej kredy. Są to złoża przede wszystkim ropne i ropno-gazowe, ale także gazowe. Obiekty te są związane z obszarem bloku małopolskiego, a więc występują w strefie między Krakowem a Rzeszowem, np. złoża: Grobla, Pławowice, Łąkta, Swarzów, Dąbrowa Tarnowska, Smęgorzów, Partynia-Podborze, Tarnów, Brzezówka, Nosówka.

Według dotychczasowej wiedzy dotyczącej budowy geologicznej tych złóż skałami zbiornikowymi są tu przede wszystkim piaskowce cenomanu, a $\mathrm{w}$ drugim rzędzie wapienie jury oraz turonu. Uważano, że pojemność zbiornikowa w tych skałach jest związana przede wszystkim z porowatością międzyziarnową piaskowców cenomanu i wapieni górnojurajskich, a podrzędnie również ze szczelinowatością wapieni turonu i jury.

Powyższa interpretacja rodzaju porowatości skał zbiornikowych jest prawdziwa, ale wydaje się niepełna. Nie uwzględnia bowiem praktycznie (poza lokalnym udziałem porowatości szczelinowej) porowatości związanej z obecnością zjawisk krasowych w utworach wapieni górnojurajskich. Zjawiska krasowe w wapieniach górnojurajskich występują bardzo powszechnie na obszarze Jury Krakowsko-Częstochowskiej i są reprezentowane przez różne formy krasowe, jak np.: małe jamki, kanaliki krasowe, leje krasowe, studnie krasowe, groty, jaskinie, korytarze itp. (Urban i Rzońca, 2009; Felisiak, 2016; Wódka i Wójcik, 2016). Nie ma powodu, by te formy nie występowały również w formie kopalnej, jako tzw. paleokras, czyli kras kopalny, na co są zresztą liczne dowody zarówno w Polsce, jak i na świecie (Zhang i Liu, 2009; Szulc et al., 2015; Wójcik et al., 2015; Bardziński i Kurowska, 2017; Cao et al., 2017; Gao et al., 2018). Rejon przedgórza karpackiego po osadzeniu wapieni górnojurajskich był wielokrotnie poddany procesom erozyjnym w warunkach wietrzenia lądowego, m.in. w dolnej kredzie i paleogenie. Były to wystarczająco długie okresy do powstania różnego rodzaju form krasowych. Podczas transgresji mioceńskiej przykarpacka część zapadliska przedkarpackiego, w tym erozyjna powierzchnia jury, została zanurzona i przykryta osadami mioceńskimi (Oszczypko, 2006; Gutowski et al., 2007). Istniejące formy krasowe zostały pogrążone również razem ze skałami, wśród których powstały. Część z tych pogrążonych form krasowych została wypełniona osadem, częściowo lub całkowicie, a część - i to zapewne znaczna - pozostała pusta, wypełniona początkowo wodą słodką lub morską. Następnie w okresie formowania się złóż węglowodorów pustki krasowe w korzystnych warunkach zostały wypełnione węglowodorami: ropą i gazem. Niektóre z tych złóż w rejonie zapadliska przedkarpackiego zostały już odkryte i zapewne na wielu z nich część objętości porowej stanowią różne formy paleokrasu, dotychczas jeszcze niezidentyfikowane i słabo albo w ogóle nieudostępnione do eksploatacji.

O tym, jak istotne znaczenie może mieć paleokras dla złóż węglowodorów, może świadczyć przykład Chin, gdzie odkryto wiele złóż ropy naftowej i gazu właśnie w paleokrasie (Zhang i Liu, 2009; Lin et al., 2012; Sun et al., 2013; Jiang et al., 2015; Dai et al., 2017; Tian et al., 2017; Gao et al., 2018). Na przykład w basenie Tarim, położonym w NW Chinach, zasoby ropy i gazu występujące w strukturach krasowych oceniane są na $113,55 \times 10^{8}$ t ropy naftowej i $13,183 \times 10^{12} \mathrm{~m}^{3}$ gazu. Paleokras występuje tam w postaci jaskiń, studni, korytarzy itp. i związany jest $\mathrm{z}$ wapieniami dolnego ordowiku. Podobne złoża spotyka się w wielu innych rejonach Chin, np. w Syczuanie, Tabei, Jingbin, Ordos Basin, a także świata (Russell, 2007; Black, 2012, Dai et al., 2017). Należy sądzić, że również w Polsce istnieje szansa na odkrycie tego typu złóż. 


\section{Budowa geologiczna rejonu badań i jego historia geologiczna w mezozoiku oraz kenozoiku}

W celu ustalenia możliwości występowania form paleokrasu w utworach jury $\mathrm{i}$ ich znaczenia w procesie akumulacji złóż gazu oraz eksploatacji tych złóż został przeanalizowany obszar podłoża zapadliska przedkarpackiego w rejonie Swarzów-Smęgorzów i Dąbrowa Tarnowska (rys. 1), w którym występują złoża gazowe i ropno-gazowe, a skałami zbiornikowymi są piaskowce cenomanu, wapienie jury oraz wapienie turonu (Dudek, 1980). W ujęciu regionalnym rejon Swarzów-SmęgorzówDąbrowa Tarnowska (Sw-Sm-DT) występuje na obszarze niecki miechowskiej, stanowiącej SE część synklinorium szczecińsko-łódzko-miechowskiego. Rejon Sw-Sm-DT położony jest w części środkowej niecki. W tej jej części utworami budującymi powierzchnię podłoża podmioceńskiego są utwory górnej jury oraz górnej kredy (Barbacki i Kazanowska, 2001; Barbacki, 2002).

Stratygrafia utworów podmioceńskich przedstawia się następująco. Począwszy od góry profilu są wydzielane:

- utwory górnej kredy - są to margle senonu podścielane wapieniami turonu, poniżej których występują piaskowce i zlepieńce cenomanu;

- utwory górnej jury - są to wapienie z marglami;

- utwory środkowej jury - są to wapienie keloweju;

- utwory triasu - reprezentowane przez wapienie i margle wapienia muszlowego i retyku (nierozdzielone);

- utwory permu - pstrego piaskowca niższego (nierozdzielone) - reprezentowane przez: iłowce, piaskowce, łupki i zlepieńce;

- utwory karbonu dolnego - są reprezentowane przez piaskowce, łupki i wapienie, a w spągu - zlepieńce;

- utwory dewonu - reprezentowane przez wapienie.

Utwory dewonu są to najstarsze nawiercone w tym rejonie osady. W kierunku na wschód od rejonu badań, w otworze Podborze 10, poniżej skał dewońskich nawiercono skały prekambryjskie reprezentowane przez sfyllityzowane iłowce. Utwory starsze od permu należą do starszej jednostki paleozoicznej, a mianowicie bloku małopolskiego.

Na różnowiekowych utworach podłoża skał podłoża zalegają osady miocenu autochtonicznego zapadliska przedkarpackiego wieku baden-sarmat (Oszczypko, 2006; Urbaniec, 2017). Osady miocenu są tu tradycyjnie rozdzielone na trzy zasadnicze serie:

- warstwy baranowskie - wykształcone, jako osady piaszczysto-ilaste badenu wczesnego do badenu późnego;

- formacja z Krzyżanowic - reprezentowana przez ewaporaty późnego badenu;

- formacja z Machowa - reprezentowana przez osady piaszczysto-ilaste późnego badenu i sarmatu.

Rys. 1. Uproszczona mapa geologiczna niecki miechowskiej i przyległej części zapa-

Fig. 1. Basic geological map of the Miechów Trough and the adjacent part of the Carpathian Foredeep (after Stachacz et al., 2013); the research area (Swarzów-Smęgorzów-Dąbrowa Tarnowska) is marked on the map

Miąższość utworów miocenu w rejonie badań rośnie od 350-450 m na północy do 700-1000 m w części południowej.

Jak wspomniano powyżej, na powierzchni podmioceńskiej w rejonie badań występują różnowiekowe osady mezozoiku, od górnej jury do górnej kredy - senonu. Wykształcenie tych utworów na podstawie wierceń przedstawia się następująco:

- górna jura - utwory górnej jury reprezentowane są przez wapienie detrytyczne, organogeniczne, oolitowe, onkolitowe, muszlowcowe, biohermowe, margliste, wapienie margliste oraz margle i dolomity. Miąższość osadów górnej jury dochodzi do około $1000 \mathrm{~m}$ (Sw-9);

- górna kreda:

- cenoman - zielone i szare piaskowce drobnoziarniste do gruboziarnistych, czasami zlepieńcowate, glaukonitowe, rozsypliwe, z wkładkami zielonych łupków ilastych, a w górze również białych wapieni. Miąższość piaskowców zmienia się w zakresie od 0 do kilkunastu metrów, 
- turon - wapienie barwy białej, szarej, zielonkawej z domieszką ziaren kwarcu, glaukonitu, najczęściej organogeniczne, margliste, silnie spękane z wypełnieniem zieloną substancją ilastą lub piaszczystą, w dolnej części profilu występują przekładki zielonego piaskowca glaukonitowego. Miąższość wapieni zmienia się w zakresie do $7 \mathrm{~m}$,

- senon - margle szare, czasami zielonkawe, w dolnej części często zapiaszczone, zbite, pękające równolegle, z pęknięciami i szczelinami nierzadko wypełnionymi kalcytem. Miąższość margli senońskich w rejonie badań jest zróżnicowana i dochodzi maksymalnie do ponad $100 \mathrm{~m}$.

Obecna morfologia powierzchni podmioceńskiej (rys. 2, 3) jest efektem wielu procesów geologicznych, w tym przede wszystkim procesów tektonicznych i erozyjnych. Te ostatnie zachodziły po górnej jurze i była to najpierw erozja dolnokredowa, a następnie erozja paleogeńska.

Dla zrozumienia procesów geologicznych, które doprowadziły do wykształcenia się skał zbiornikowych złóż gazu i ropy naftowej, konieczne jest krótkie przypomnienie ewolucji geologicznej tego rejonu, począwszy od późnej jury po wczesny baden. W czasie późnej jury badany obszar był zalany przez morze, w którym deponowane były wapienie z wkładkami margli (Gutowski et al., 2007). Wapienie są reprezentowane przez różne odmiany facjalne, jak np.: wapienie biohermalne, wapienie gąbkowo-glonowe, wapienie oolitowe, onkolitowe, płytowe, koralowe itp. (Oszczypko i Tomaś, 1978). Z końcem wczesnej jury następuje regresja morza i nastają zasadniczo warunki lądowe. Podczas dolnej kredy - neokomu okresowo występują transgresje morskie, przedzielane okresami erozji lądowej, która nasila się podczas barremu, aptu i albu, powodując usunięcie osadów neokomu oraz częściowo górnej jury. W tym też okresie doszło zapewne do wystąpienia intensywnych procesów krasowych w skałach wapiennych górnej jury, których efektem było powstanie różnorodnych form krasowych. Wskazuje na to obecność charakterystycznych zielonych piaskowców cenomańskich w szczelinach, kawernach i formach krasu zidentyfikowanych jako jaskinie, co świadczy, że podczas transgresji cenomańskiej powyższe formy krasu musiały już istnieć.

W cenomanie po okresie erozji dolnokredowej ma miejsce transgresja morska, która trwa na badanym obszarze przez całą górną kredę. Powstają w tym czasie piaskowce cenomanu, wapienie turonu oraz skały margliste senonu.

W późnym mastrychcie morze uległo regresji i ponownie w badanym rejonie nastały warunki lądowe oraz czas erozji.

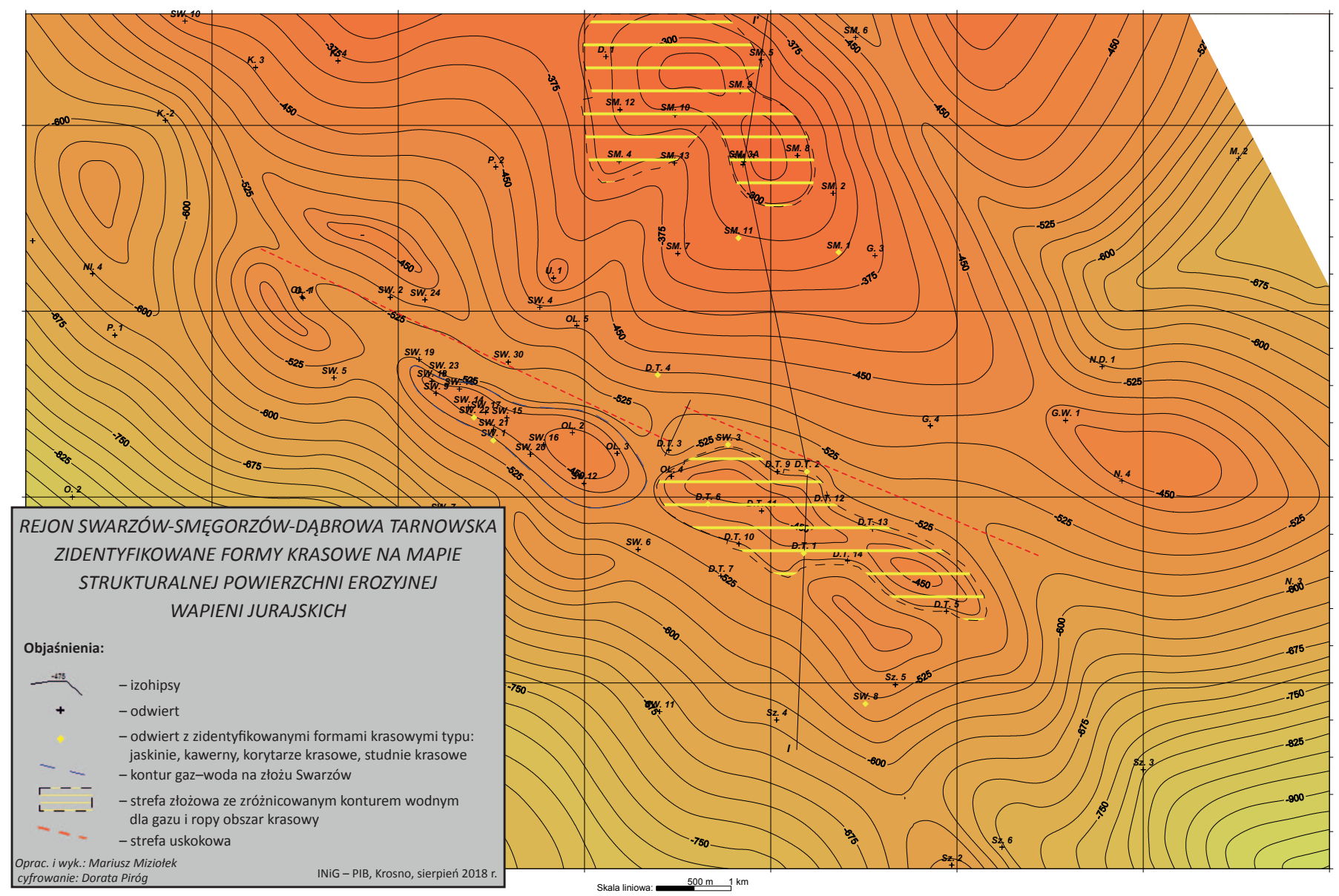

Rys. 2. Mapa strukturalna erozyjnej powierzchni górnej jury z naniesionymi lokalizacjami zidentyfikowanych form paleokrasu

Fig. 2. Structural map of the Upper Jurassic erosive surface with the locations of the identified paleokarst forms 


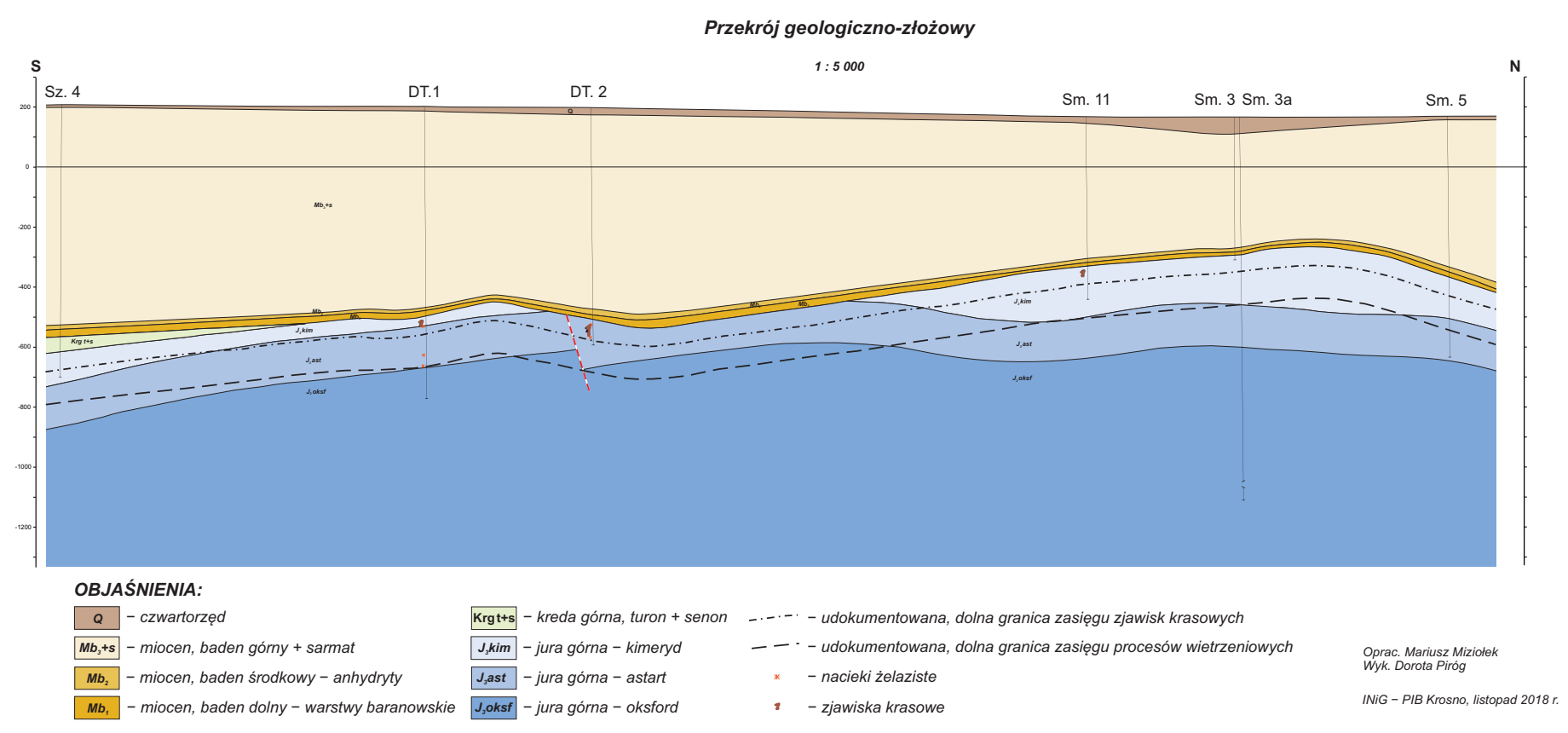

Rys 3. Przekrój geologiczny przez rejon Swarzów-Smęgorzów-Dąbrowa Tarnowska. Na przekroju zastosowano archiwalny podział stratygrafii miocenu i górnej jury

Fig. 3. Geological cross-section through the Swarzów-Smęgorzów-Dąbrowa Tarnowska region. The former lithostratigraphic divisions of Miocene and Upper Jurassic were used on the cross-section

Erozja, trwająca do końca oligocenu, spowodowała częściowe lub całkowite usunięcie osadów górnokredowych, a w tych miejscach, gdzie doszło do ich całkowitego usunięcia, objęła również utwory górnojurajskie, co doprowadziło do ponownego uruchomienia procesów krasowych. W rejonie badań całkowite usunięcie osadów kredowych wystąpiło na NE od Swarzowa, z objęciem części złoża Swarzów i Smęgorzów i w całości złoża Dąbrowy Tarnowskiej. W tych odsłoniętych strefach z jednej strony doszło zapewne do odnowienia i pogłębienia istniejących form krasu, a z drugiej strony - do powstania nowych form krasowych. Bardzo możliwe, że powstało nowe piętro krasowe w obrębie wapieni jury. W kierunku SW od złoża Swarzów osady górnej kredy nie zostały zerodowane i przetrwały.

W miocenie miała miejsce ponowna transgresja morska, która doprowadziła do złożenia w rejonie Sw-Sm-DT miąższych osadów molasowych wypełniających też cały obszar zapadliska przedkarpackiego (Radwański, 1968).

Podsumowując jurajsko-kenozoiczną ewolucję geologiczną rejonu badań, należy zaznaczyć, że co najmniej dwukrotnie doszło tu do uruchomienia procesów krasowych, a mianowicie:

- podczas wczesnej kredy procesy krasowe objęły cały rejon Sw-Sm-DT;

- podczas paleogenu procesy krasowe objęły części obszaru położone w kierunku na NE i E od Swarzowa, obejmując swym zasięgiem NE część złoża Swarzów i większą część złoża Smęgorzów oraz cały obszar rejonu Dąbrowy Tarnowskiej.

\section{Metodyka i zakres badań}

W celu identyfikacji ewentualnych form paleokrasu w rejonie Sw-Sm-DT przeprowadzono reinterpretację następujących materiałów (Katalog wierceń górnictwa naftowego w Polsce, 1970):

- opisu rdzeni wiertniczych;

- opisu prac wiertniczych i wyników opróbowania;

- pomiarów geofizycznych.

Analiza opisu rdzeni stanowiła podstawę do wydzielenia i identyfikacji różnych form krasowych. Była to praca o tyle trudna, że opisy pochodzące $z$ lat 60 . i 70. zupełnie nie uwzględniały możliwości występowania dużych form pogrążonego głęboko paleokrasu, dlatego nie zwracano uwagi na elementy istotne dla zjawisk i form krasowych. Pomimo to na kilkadziesiąt analizowanych otworów, aż w 13 przypadkach wydzielono struktury, które zidentyfikowano jako formy krasowe, choć być może pewna ich część może budzić wątpliwości interpretacyjne.

Analiza opisu prac wiertniczych była również bardzo pomocna w identyfikacji struktur krasowych. W kilku otworach zanotowano podczas wiercenia, opróbowania i cementowania liczne ucieczki płuczki lub cementu, sygnałem obecności krasu był też niski uzysk rdzenia, jego silne rozkruszenie. Takie zjawiska sugerowały możliwość wystąpienia pustek krasowych, częściowo wypełnionych lub niewypełnionych osadem.

Analiza pomiarów geofizycznych przynosiła różne wyniki. Analizowano przede wszystkim profilowania gamma, opornościowe (PO) oraz wyniki pomiaru kawernomierzem. W przypadku gdy osady pustek krasowych różniły się zdecydowanie 
od skał otaczających, wtedy łatwo można było zauważyć zmiany na zapisie gamma oraz PO. Jeśli osad wypełniający pustki był luźny i został wypłukany lub formy krasowe były niewypełnione, wtedy na kawernomierzu rejestrowano znaczne zwiększenie średnicy. W przypadku otworów, w których zidentyfikowano formy krasowe, a wypełniające je utwory nie odbiegały litologicznie od skał otaczających i były zbite, wyodrębnienie na karotażu struktur krasowych było bardzo utrudnione lub niemożliwe.

Kryteria, jakimi kierowano się przy identyfikacji przypuszczalnych form paleokrasu, były zróżnicowane, a najważniejsze z nich są następujące:

- duża zmienność litologiczna;

- odmienność litologiczna osadów w stosunku do przewiercanego profilu;

- obecność osadów ilastych barwy: czarnej, czerwonej, brązowej, zielonej;

- obecność brekcji wapiennej;

- obecność mułowców, piaskowców, zlepieńców;

- zmienność kątów upadu;

- obecność pustek, kawern, szczelin;

- nagłe załamania krzywej gamma od wapieni do łupków ilastych;

- nagłe poszerzenie średnicy otworu do dużych rozmiarów. Powyższe kryteria występowały niekiedy wspólnie, wtedy identyfikacja form krasowych była pewniejsza; w innych wypadkach wspomniane kryteria występowały pojedynczo i wtedy identyfikacja była utrudniona.

\section{Identyfikacja paleokrasu - przykłady i udokumentowane formy krasowe}

Łącznie - jak to wspomniano wcześniej - przeprowadzono analizy opisu rdzeni i innych danych wiertniczych pochodzących z kilkudziesięciu otworów. W 13 otworach zostały zidentyfikowane różne formy krasowe, $z$ tej liczby 4 otwory zlokalizowane są w rejonie Swarzowa, 4 w rejonie Smęgorzowa i 6 w rejonie złoża Dąbrowa Tarnowska. Otwory ze zidentyfikowanym paleokrasem zostały przedstawione na tle mapy strukturalnej podłoża jurajskiego.

Na rysunkach 4, 5 i 6 przedstawiono profile 3 otworów reprezentujących rejon badań Swarzów-Smęgorzów-Dąbrowa Tarnowska. Są to profile geologiczne opracowane na podstawie opisu rdzeni wiertniczych, na których zaznaczono interwały zidentyfikowanych form krasowych.

Na kolejnych rysunkach - 7, 8 i 9 przedstawiono identyfikacje form krasowych na profilowaniach geofizyki otworowej, w skład których wchodziły: pomiar gamma, profilowanie oporności i średnicy.

Wyniki przeprowadzonej analizy i reinterpretacji opisów rdzeni wiertniczych przedstawiono w tabeli 1 . Ze względu na to, że opis rdzeni jest bardzo ogólny, to identyfikacja form krasowych też jest na poziomie ogólnym. Najczęściej występującą formę krasową o naturze tektoniczno-krasowej stanowią szczeliny, które są albo wolne, albo wypełnione osadem utworzonym w okresie erozji i procesów krasowych. Szczeliny najczęściej wypełnione są osadem ilastym lub piaszczystym

\section{Profil geologiczny utworów górnej jury}

skala $1: 500$

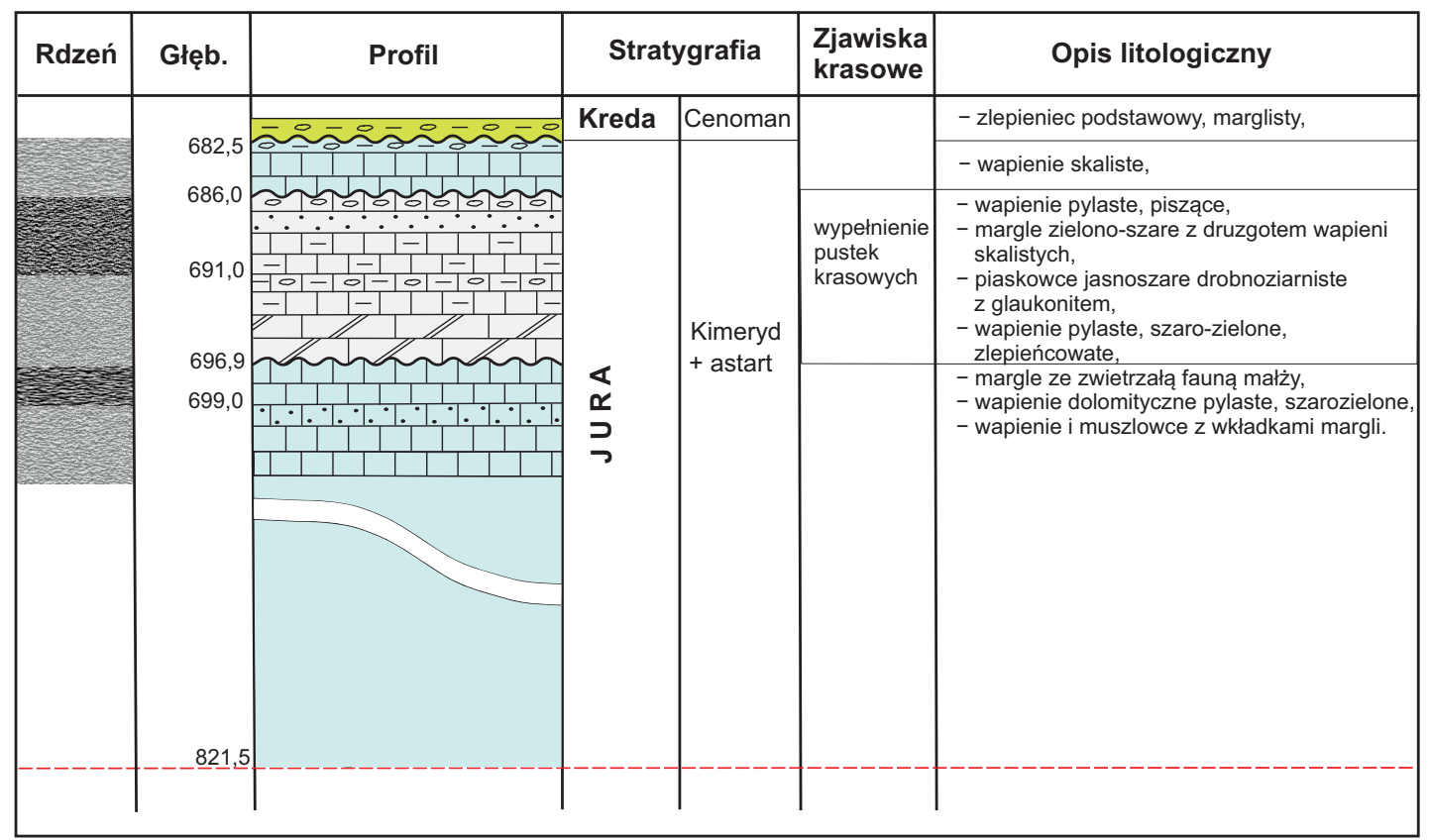

Rys. 4. Profil geologiczny przykładowego otworu z rejonu Swarzowa ze zidentyfikowanym paleokrasem

Fig. 4. Geological profile of an example well located in Swarzów region, with identified paleokarst 


\section{Profil geologiczny utworów górnej jury}

skala $1: 500$

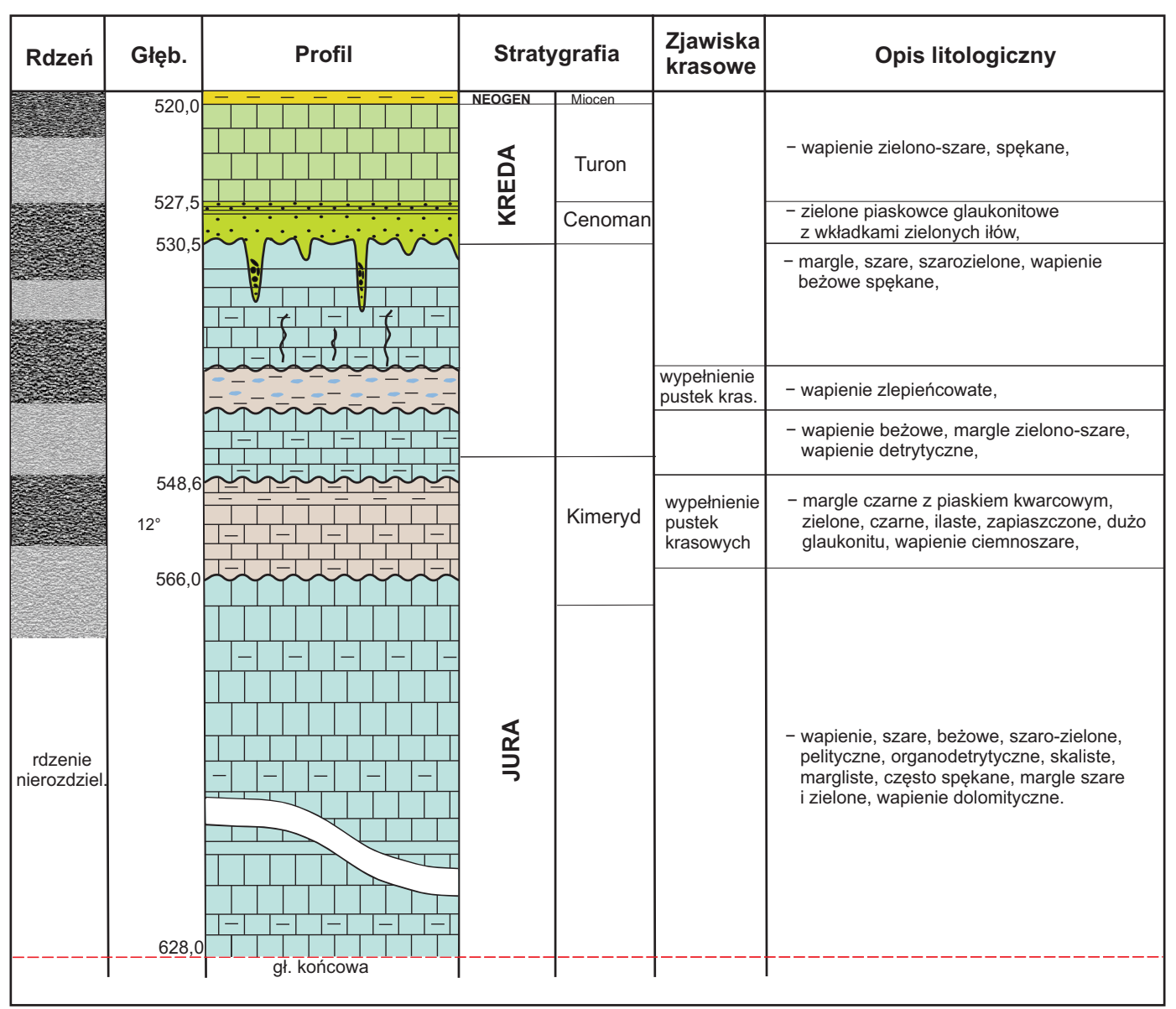

Rys. 5. Profil geologiczny przykładowego otworu z rejonu Smęgorzowa ze zidentyfikowanym paleokrasem

Fig. 5. Geological profile of an example well located in Smęgorzów region, with identified paleokarst

o barwie: zielonej, czarnej, czerwonej, czasami brązowej. W przypadku szczelin niewypełnionych często ich ściany pokryte są kolorowymi nalotami związanymi z procesem wietrzeniowym i krasowym. Występują tu kolory: rdzawe, czerwone, niebieskie, zielone i czarne.

$\mathrm{Z}$ małych form krasowych rozpoznano: małe kawerny i kanaliki oraz druzy z wypełnieniem osadowym lub kalcytowym.

Jeśli chodzi o duże formy krasowe, zidentyfikowano je w 10 otworach, z czego w 8 otworach są to struktury przypuszczalnie całkowicie lub częściowo wypełnione osadem. Natomiast w 2 otworach jest to na pewno tylko częściowe wypełnienie jaskiń - są tu obecne pustki niewypełnione osadem, co potwierdzają liczne ucieczki płuczki oraz cementu. Wydzielone duże formy krasowe w części są na pewno jaskiniami (w znaczeniu sala czy komora krasowa), ale mogą być wśród nich także korytarze krasowe, studnie i leje krasowe, jamy, duże kanały itp., wielkość dużych form krasowych jest zróżnicowana. Wydzielone w otworach formy krasowe mają wielkość w profilu pionowym od $3 \mathrm{~m}$ do $18 \mathrm{~m}$, a być może nawet $38 \mathrm{~m}$.

\section{Uwarunkowania geologiczne pułapek złożowych w skałach jurajskich podłoża podmioceńskiego i dyskusja wyników badań}

W rejonie Swarzów-Smęgorzów-Dąbrowa Tarnowska złoża węglowodorów odkryto wyłącznie w utworach podłoża podmioceńskiego i były to:

- złoże gazu ziemnego Swarzów - w utworach górnej jury i górnej kredy, którymi były piaskowce cenomanu i wapienie turonu;

- złoże gazu ziemnego i ropy w Smęgorzowie - odkryte w wapieniach górnej jury i piaskowcach górnej kredy - cenomanie;

- złoże ropy naftowej i gazu ziemnego w Dąbrowie Tarnowskiej - odkryte w wapieniach górnej jury.

Wszystkie trzy złoża związane są strukturalnie z wyniesieniami podłoża (rys. 2, 3) i jeżeli chodzi o ich pułapki złożowe, wykazują między sobą pewne podobieństwa, ale też i różnice. Na wszystkich tych złożach jedną ze skał zbiornikowych lub jedyną są utwory górnej jury. Utwory górnej jury, zarówno w obrębie złóż, jak i poza nimi, można podzielić na 3 strefy, które charakteryzują się różnymi właściwościami. 


\section{Profil geologiczny utworów górnej jury}

Skala $1: 500$

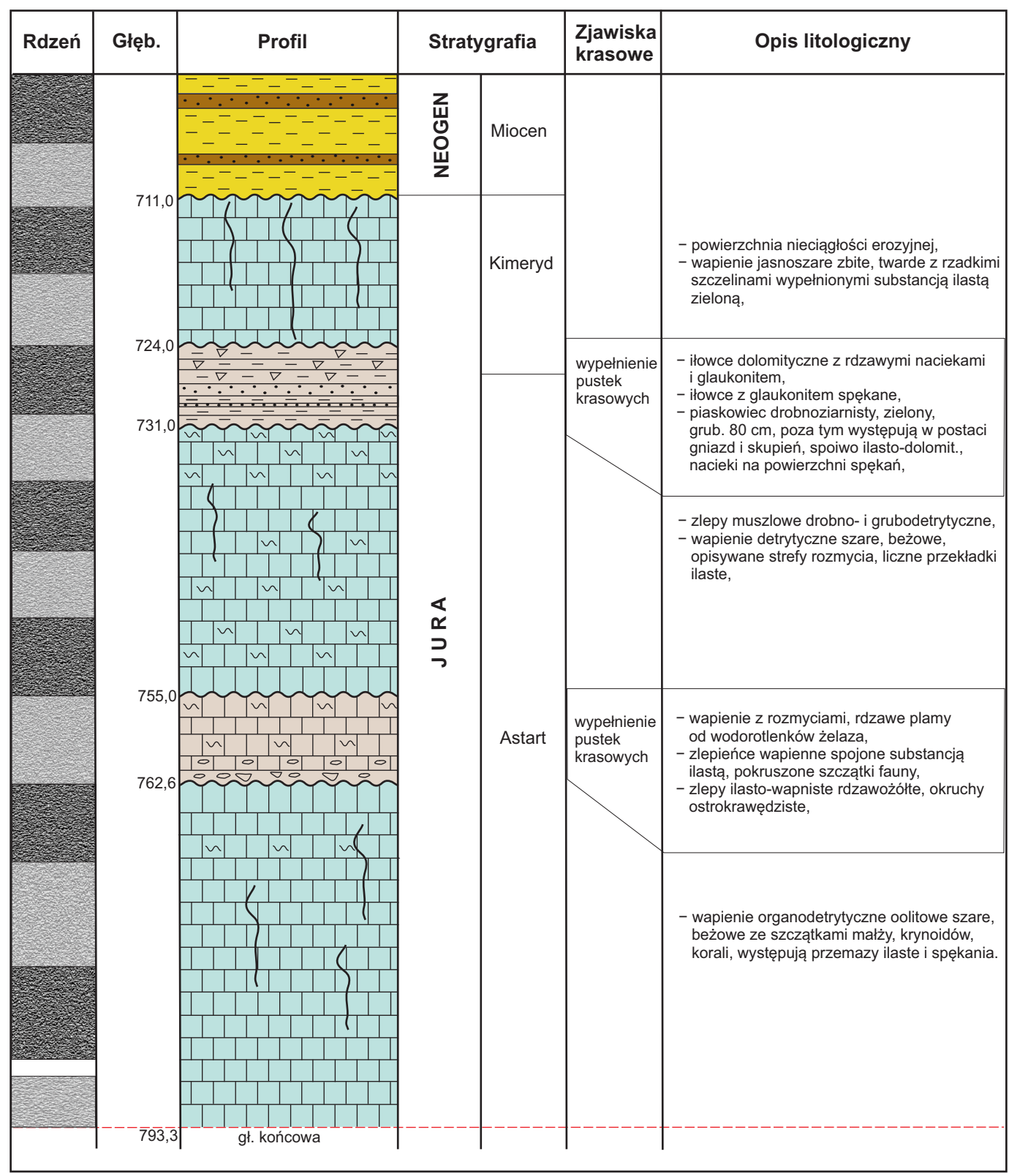

Rys. 6. Profil geologiczny przykładowego otworu z rejonu Dąbrowy Tarnowskiej ze zidentyfikowanym paleokrasem

Fig. 6. Geological profile of an example well located in Dąbrowa Tarnowska region, with identified paleokarst

- Strefa stropowej powierzchni utworów jury górnej - ma charakter powierzchni erozyjnej, która jest wynikiem procesów erozyjnych mających miejsce w dolnej kredzie oraz w paleogenie.

Znalezione w opisach rdzeni dowody (np. w otworach Dąbrowa Tarnowska-1, -2, Smęgorzów-11 i -1) na występowanie w skałach jurajskich form i osadów związanych z krasem wskazują, że oprócz erozji rozwinęły się na badanym obszarze silne zjawiska krasowe, których objawy związane są zarówno z powierzchnią erozyjną, jak i strefą skał jurajskich położonych poniżej tej powierzchni (Gradziński, 1995; Gutowski et al., 2007; Gradziński et al., 2008). Jest ona zbudowana albo z litych lub spękanych skał wa- piennych, albo też ze zwietrzeliny, w obrębie której tkwią fragmenty i okruchy skał jurajskich. Jak wskazują na to pewne fakty, czyli: opisy rdzeni, pomiary geofizyczne, objawy w czasie wiercenia oraz przebieg eksploatacji złoża, powierzchnia erozyjna zawiera różne elementy form krasowych. Należą do nich: spękania - mniej lub bardziej poddane procesom krasowym, leje krasowe, otwory studzien krasowych, ujścia komór, grot i jaskiń. Formy te rozwijają się w głąb utworów jury i są całkowicie lub częściowo wypełnione osadem albo krasowym, albo pochodzącym z morskiej transgresji kredowej i/lub mioceńskiej (Radwański, 1968; Wójcik et al., 2015; Wódka i Wójcik, 2016). Formy krasowe odgrywają bardzo istotną rolę, gdyż wobec słabych na 


\section{Pomiary geofizyczne: PG, PO i kawernomierz dokumentujące formy paleokrasu - jaskinie}

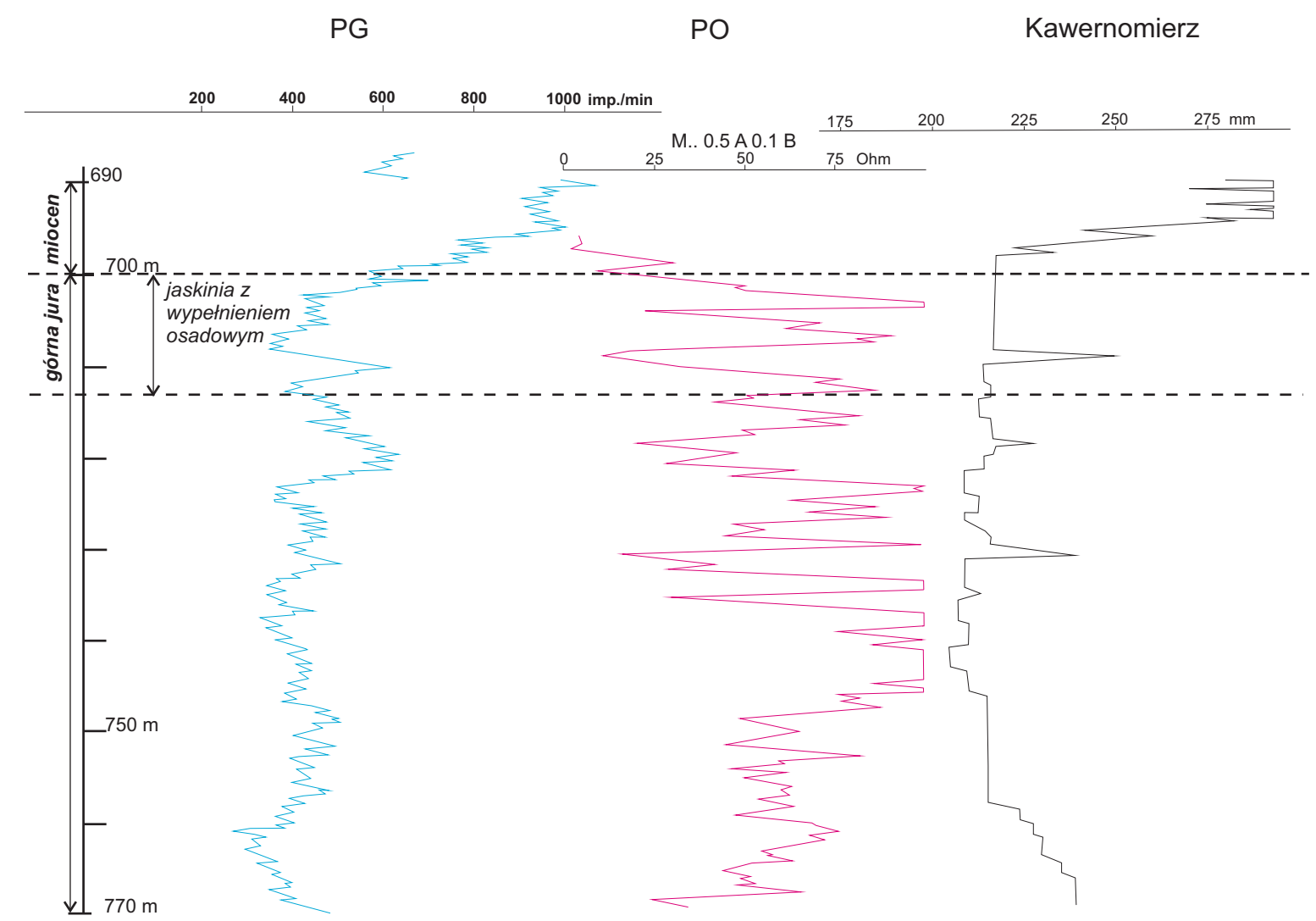

Rys. 7. Pomiary geofizyczne dokumentujące formy krasowe na odwiercie z rejonu Swarzowa

Fig. 7. Geophysical measurements documenting karst forms in a well located in Swarzów region

ogół parametrów petrofizycznych skał wapiennych są łącznikami hydrodynamicznymi strefy zwietrzałej wapieni jurajskich i strefy głębokiego krasu z wyżej leżącymi (np. na Swarzowie) piaskowcami cenomańskimi. Łączność ta występuje oczywiście w tych miejscach, gdzie spękania, szczeliny, otwory krasowe są puste, częściowo wypełnione lub wypełnione materiałem przepuszczalnym. W przypadku studzien krasowych, kawern, jaskiń łączność ma charakter punktowy, natomiast w przypadku szczelin łączność ma charakter linijny, wielopunktowy lub mieszany.

- Strefa zwietrzenia wapieni jurajskich - ma ona miąższość od 0 do kilkunastu metrów, charakteryzuje się obecnością produktów erozji oraz silnie spękanych i skawernowanych skał jurajskich, co jest efektem procesów erozyjnych i krasowych. W dół profilu skał jurajskich efekty erozyjne stopniowo zanikają. W obrębie tej strefy należy się spodziewać najczęściej występowania różnych elementów lub całych form krasowych, jak np.: szczelin, studzien krasowych, korytarzy, kominów i kawern krasowych, i sporadycznie jaskiń (np. otwory Swarzów-3, -22, Dąbrowa Tarnowska-7). Spękania, szczeliny i wymienione powyżej formy krasowe bardzo często są częściowo lub całkowicie wypełnione albo materiałem kredowym - zielone iły, piaskowce cenomanu, albo rezyduum pokrasowym barwy najczęściej czarnej, czasami czerwonej. Ściany spękań bardzo często pokrywają różnobarwne naloty barwy rdzawej, świadczącej o środowisku utleniającym, czyli wyniesionym ponad poziom morza. Występują też naloty sinoniebieskie, szaroniebieskie, ciemnoszare.

- Strefa paleokrasu wapieni jurajskich - występuje na głębokości od kilku do co najmniej kilkudziesięciu metrów. Najgłębiej udokumentowano formy krasowe w otworze Dąbrowa Tarnowska-2 - około $50 \mathrm{~m}$ poniżej powierzchni podłoża jurajskiego. Objawy zasięgu wietrzenia skał najniżej stwierdzono natomiast w otworze Dąbrowa Tarnowska-1, na głębokości około -870 m p.p.t., czyli około $165 \mathrm{~m}$ poniżej obecnej powierzchni strukturalnej jury w tym otworze. Na tej głębokości stwierdzono nacieki żelaziste na powierzchni spękań, które są charakterystyczne dla strefy wietrzeniowej, położonej powyżej zwierciadła wód podziemnych. W strefie paleokrasu zostały stwierdzone najprawdopodobniej różne formy krasowe, a mianowicie: paleojaskinie, całkowicie lub częściowo wypełnione osadem (rezyduum oraz materiałem napływowym), szczeliny i rozmycia krasowe puste lub $z$ wypełnieniem i naciekami, mniejsze lub większe kawerny i kanały krasowe również z wypełnieniem, częściowym wypełnieniem lub 
Pomiary geofizyczne: PG i PO dokumentujące formy paleokrasu - jaskinie

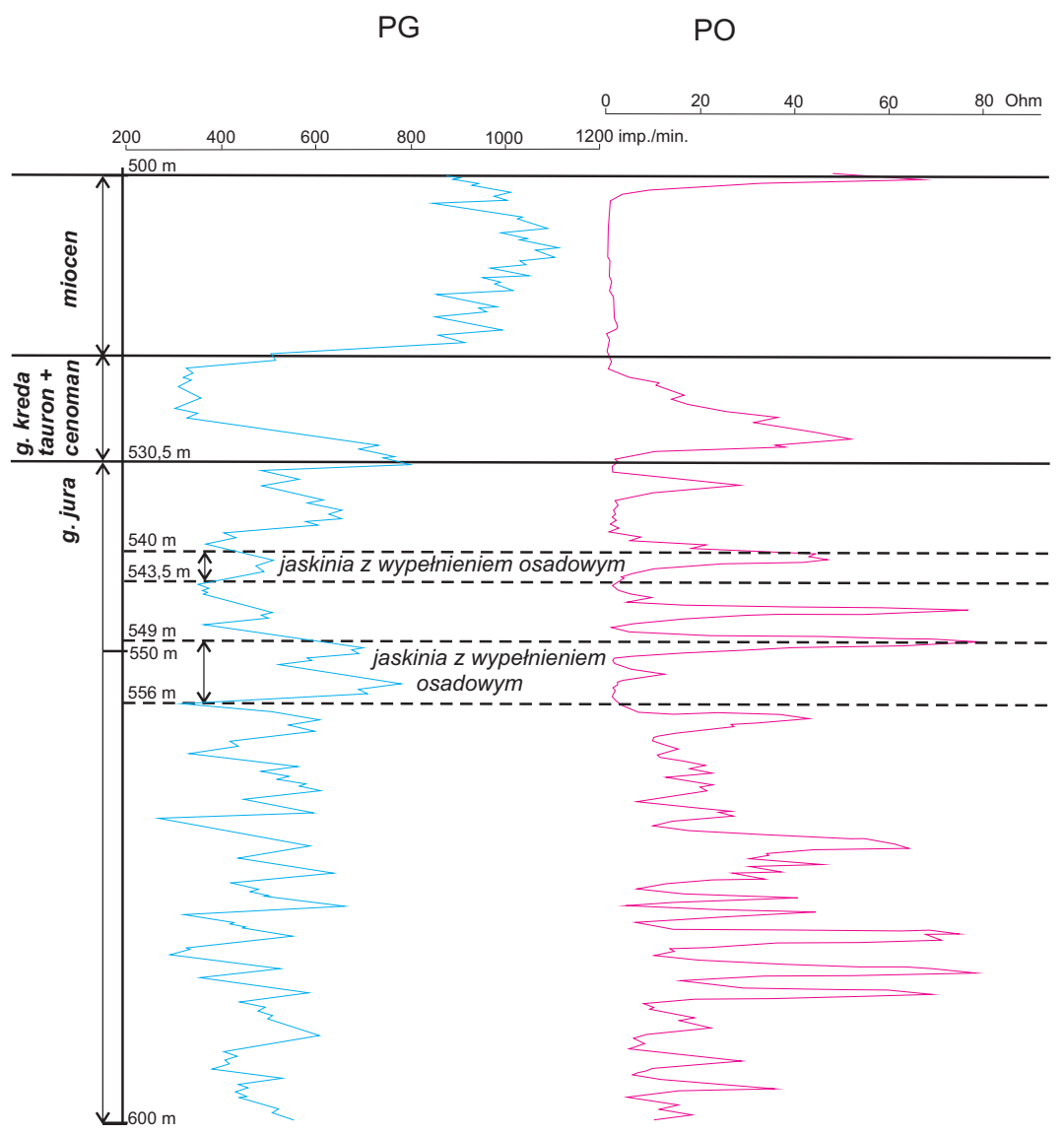

Rys. 8. Pomiary geofizyczne dokumentujące formy krasowe w odwiercie z rejonu Smęgorzowa

Fig. 8. Geophysical measurements documenting karst forms in the well located in Smęgorzów region

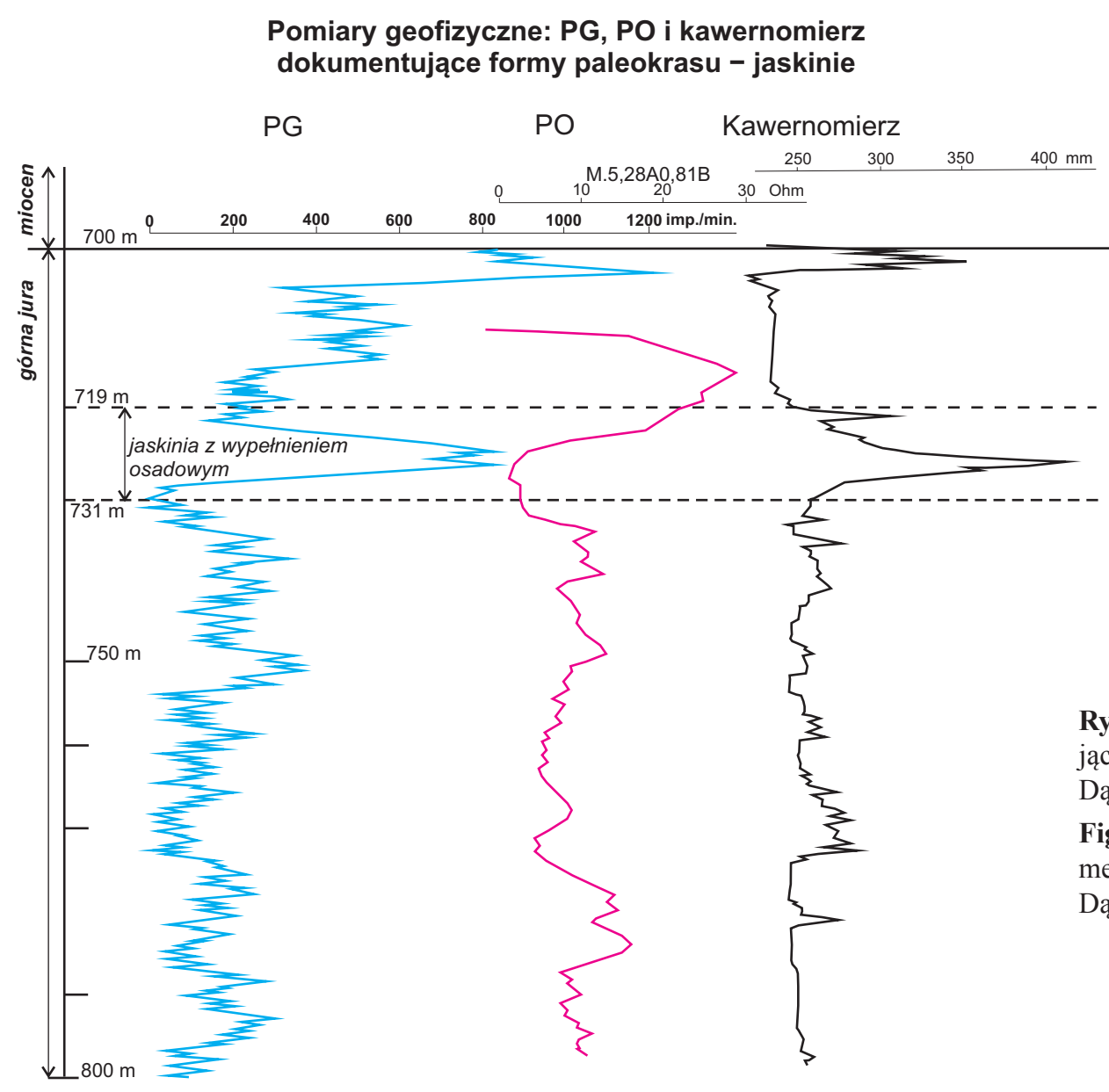

Rys. 9. Pomiary geofizyczne dokumentujące formy krasowe w odwiercie $\mathrm{z}$ rejonu Dąbrowy Tarnowskiej

Fig. 9. Geophysical measurements documenting karst forms in the well located in Dąbrowa Tarnowska region 
Tabela 1. Zestawienie form krasowych zidentyfikowanych w otworach rejonu Swarzów-Smęgorzów-Dąbrowa Tarnowska

Table 1. List of karst forms identified in wells located in the Swarzów-Smęgorzów-Dąbrowa Tarnowska area

\begin{tabular}{|c|c|c|c|c|c|c|c|c|}
\hline Odwiert & $\begin{array}{c}\text { Szczeliny } \\
\text { z zielonym } \\
\text { lub czarnym } \\
\text { wypelnie- } \\
\text { niem } \\
\end{array}$ & $\begin{array}{c}\text { Szczeliny } \\
\text { z czerwo- } \\
\text { nym wypel- } \\
\text { nieniem }\end{array}$ & $\begin{array}{l}\text { Szczeliny } \\
\text { z rdzawy- } \\
\text { mi nalo- } \\
\text { tami }\end{array}$ & $\begin{array}{c}\text { Naloty na } \\
\text { wapieniach } \\
\text { niebieskie, } \\
\text { zielone, } \\
\text { czerwone } \\
\end{array}$ & $\begin{array}{c}\text { Małe } \\
\text { kawerny } \\
\text { i kanaliki }\end{array}$ & $\begin{array}{c}\text { Druzy } \\
\text { z wypel- } \\
\text { nieniem }\end{array}$ & $\begin{array}{c}\text { Jaskinie, duże } \\
\text { kanały, studnie } \\
\text { i leje krasowe, } \\
\text { jamy z wypel- } \\
\text { nieniem } \\
\end{array}$ & $\begin{array}{c}\text { Jaskinie, duże } \\
\text { kanały i jamy } \\
\text { częściowo wypel- } \\
\text { nione, z pustkami } \\
\text { (ucieczki płuczki) }\end{array}$ \\
\hline Swarzów-1 & & & & & + & & $+(11 \mathrm{~m})$ & \\
\hline Swarzów-3 & & + & & + & & & $+(13 \mathrm{~m})$ & \\
\hline Swarzów-8 & & & & & & & $+(7 \mathrm{~m})$ & \\
\hline Swarzów-22 & & & + & & + & + & $+(3+7 \mathrm{~m})$ & \\
\hline Smęgorzów-1 & + & & & & & & $+($ ok. 7 m) & \\
\hline Smęgorzów-4 & + & & + & & & & & \\
\hline Smęgorzów-11 & + & & & & & & $+(6 \mathrm{~m})$ & \\
\hline $\begin{array}{l}\text { Dąbrowa } \\
\text { Tarnowska-1 }\end{array}$ & + & & & + & + & & & $+(18 \mathrm{~m})$ \\
\hline $\begin{array}{l}\text { Dąbrowa } \\
\text { Tarnowska-2 }\end{array}$ & & & + & + & & + & & $\begin{array}{c}+(7 \mathrm{~m}) \text { lub } \\
(38 \mathrm{~m})\end{array}$ \\
\hline $\begin{array}{l}\text { Dąbrowa } \\
\text { Tarnowska-4 }\end{array}$ & + & + & + & & + & & $+(5-6 \mathrm{~m})$ & \\
\hline $\begin{array}{l}\text { Dąbrowa } \\
\text { Tarnowska-5 }\end{array}$ & + & & + & + & + & & & \\
\hline $\begin{array}{l}\text { Dąbrowa } \\
\text { Tarnowska-6 }\end{array}$ & + & & & & $+\quad+$ & & $+($ do $11 \mathrm{~m})$ & \\
\hline \multirow[t]{2}{*}{$\begin{array}{l}\text { Dąbrowa } \\
\text { Tarnowska-7 }\end{array}$} & + & & & & & + & & \\
\hline & 8 & 2 & 5 & 4 & 5 & 3 & 8 & 2 \\
\hline
\end{tabular}

puste (przykładem częściowo niewypełnionych jaskiń są prawdopodobnie utwory jurajskie nawiercone przez otwory Dąbrowa Tarnowska-1 i -2). Zapewne obecne są też w badanym obszarze inne duże formy krasowe, takie jak studnie krasowe czy też korytarze. Te duże formy krasowe są najbardziej istotne jako zbiorniki dla ropy oraz gazu, a ich wielkość ma zasadnicze znaczenie dla zasobów. Na podstawie reinterpretacji opisu rdzeni i pomiarów geofizycznych wysokość form paleokrasu można ocenić na 3-18 m. Nie jest natomiast znana ich długość i szerokość. Struktury paleokrasu rozpoznane w otworach są w różnym stopniu wypełnione osadem, ale wobec niepełnych rdzeni trudno ocenić, w jakim stopniu.

W kilku otworach, np. na złożu Dąbrowa Tarnowska, zostały stwierdzone struktury krasowe o częściowym wypełnieniu form krasowych (Dąbrowa Tarnowska-1 i -2), gdzie podczas wiercenia $w$ interwale wydzielonych form krasowych odnotowano liczne ucieczki płuczki oraz cementów. Ucieczki płuczki sugerują, że mogą to być wolne przestrzenie w obrębie jaskiń, korytarzy czy też studni krasowych. Pojedyncze jaskinie, studnie, korytarze krasowe lub ich połączony zespół tworzą system krasu stanowiący jedność pod względem hydrodynamicznym. Taki system może być niezależny od sąsiednich systemów krasowych albo się z nimi łączyć. Czasem tak, jak ma to miejsce na Swarzowie, sąsiadujące, niezależne dynamicznie systemy krasowe mogą być połączone, pod warunkiem że mają łączność z powierzchnią erozyjną jury, przykrytą przez piaskowiec cenomański, który dzięki swoim dobrym parametrom petrofizycznym łączy całość w jeden system dynamiczny o bardzo dobrych parametrach oraz dużych zasobach.

\section{Objętości współczesnych form krasowych jako wskaźnik możliwości zbiornikowych paleokrasu w wapieniach jurajskich}

Jeśli chodzi o pojedyncze jaskinie i systemy krasowe, objętości tych struktur mogą być różne, od kilku metrów sześciennych do milionów metrów sześciennych. Na obszarze Niecki Nidziańskiej i Wyżyny Krakowsko-Częstochowskiej znajduje się mnóstwo jaskiń i systemów krasowych (rys. 10), lecz brak jest obliczeń objętości tych struktur (Gradziński, 1962; Szulc et al., 2015).

Autor, korzystając z dostępnych w Internecie planów i przekrojów niektórych jaskiń na Wyżynie KrakowskoCzęstochowskiej, dokonał bardzo uproszczonych obliczeń ich objętości (http://jaskiniepolski.pgi.gov.pl). Miało to na celu dokonanie przybliżonej oceny wielkości współczesnych struktur krasowych z obszaru bliskiego rejonowi badań. Wyniki obliczeń przedstawiono w tabeli 2. 
Tabela 2. Przybliżone obliczenia objętości wybranych, współczesnych jaskiń z rejonu Wyżyny Krakowsko-Częstochowskiej

Table 2. Approximate calculations of the volume of selected caves occurring in the region of the Krakow-Częstochowa Upland

\begin{tabular}{|c|c|c|c|c|}
\hline \multirow{2}{*}{ Nazwa jaskini } & \multirow[t]{2}{*}{ Położenie } & Długośćć & Deniwelacja & $\begin{array}{c}\text { Przybliżona } \\
\text { objętość jaskini }\end{array}$ \\
\hline & & {$[\mathrm{m}]$} & {$[\mathrm{m}]$} & {$\left[\mathbf{m}^{3}\right]$} \\
\hline Jaskinia Wierzchowska & okolice Krakowa, Wierzchowie, Dolina Kluczwody & 975 & 25 & ok. 11500 \\
\hline Jaskinia Łokietka & Ojców & 320 & 7 & ok. 8600 \\
\hline Jaskinia Nietoperzowa & Jerzmanowice, okolice Krakowa & 326 & 23 & ok. 3500 \\
\hline Jaskinia Studnisko & Olsztyn, Sokole Góry & 285 & 74 & ok. 10000 \\
\hline Jaskinia Smocza Jama & Kraków & 276 & 15 & ok. 1500 \\
\hline Jaskinia Racławicka & okolice Krzeszowic & 168 & 26 & ok. 2200 \\
\hline
\end{tabular}

Przedstawione wyliczenia objętości oraz analiza współczesnych jaskiń prowadzi do wniosku, że na obszarze Wyżyny Krakowsko-Częstochowskiej w rejonie Krakowa występują systemy jaskiniowe, których objętość wynosi od kilkudziesięciu metrów sześciennych do kilkunastu tysięcy metrów sześciennych.

W tabeli 3 przedstawiono przykłady jaskiń z rejonu Wyżyny Krakowsko-Częstochowskiej wraz z parametrami przestrzennymi charakteryzującymi wielkość niektórych elementów systemu jaskiniowego. Z przedstawionego zestawienia wynika, że korytarze występujące $\mathrm{w}$ systemie jaskiniowym mają od kilku do 150 m długości, przy szerokości dochodzącej maksymalnie do 1-6 m. Wysokość korytarzy, niepodana w tabeli, może wynosić do kilku, kilkunastu metrów.

Bardzo ciekawe jest zestawienie głównych kierunków przebiegu korytarzy. Wynika z niego, że dominują 2 kierunki: SW-NE oraz NW-SE, sporadycznie występują kierunki N-S i WSW-ENE.

Kierunek SW-NE pokrywa się z kierunkiem ciosu poprzecznego, a NW-SE z kierunkiem ciosu podłużnego na Wyżynie Krakowsko-Częstochowskiej. Jest to więc wyraźny sygnał o preferowanych kierunkach rozwoju krasu w badanym rejonie. Powinien tu dominować kierunek SW-NE, a na drugim miejscu kierunek NW-SE. Sporadycznie mogą występować kierunki N-S i WSW-ENE.

W tabeli 3 podano też rozmiary pojedynczych, największych komór stwierdzonych w systemie jaskiń i ich maksymalne objętości (do obliczeń użyto maksymalnej wysokości komory). Zróżnicowanie objętości komór jest bardzo duże i wynosi około $84 \mathrm{~m}^{3}$ do $4500 \mathrm{~m}^{3}$. Największe objętościowo komory występują w: Jaskini Mamutowej $-4500 \mathrm{~m}^{3}$, Jaskini Lokietka $-4200 \mathrm{~m}^{3}$ oraz w Jaskini Studnisko $-3600 \mathrm{~m}^{3}$.

Oprócz tych dużych komór w systemie jaskiniowym istnieją też mniejsze komory i jest ich najczęściej do kilku sztuk. W niektórych systemach jaskiniowych nie stwierdzono występowania komór, np. w Jaskini nad
Źródłem czy też Jaskini Zbójeckiej, gdzie z kolei istnieje tylko mała komora o wymiarach $5 \times 5 \times 5 \mathrm{~m}$. Są to jednak przypadki pojedyncze, gdyż w większości jaskiń komory występują.

Długość pojedynczych jaskiń czy też systemów jaskiń na Wyżynie Krakowsko-Częstochowskiej jest zróżnicowana wynosi od kilku do około $1000 \mathrm{~m}$, średnio około $125 \mathrm{~m}$. Najdłuższa znana jaskinia na tym obszarze to Jaskinia Wierzchowska Górna, długości 975 m. Deniwelacja jaskiń, czyli różnica między wlotem a spągiem jaskini, zmienia się w zakresie $0-77,5 \mathrm{~m}$, średnio natomiast wynosi około $15 \mathrm{~m}$. Największe deniwelacje (77,5 m) występują w Jaskini Studnisko koło Olsztyna. Bliskość wyżyny i ten sam typ skał, czyli wapienie górnojurajskie, pozwalają sądzić, że również podobne formy krasowe, o podobnych wielkościach, występują w rejonie Swarzów-Smęgorzów-Dąbrowa Tarnowska. Spośród dużych form krasowych w systemie jaskiń najczęściej występują: studnie krasowe, korytarze i komory.

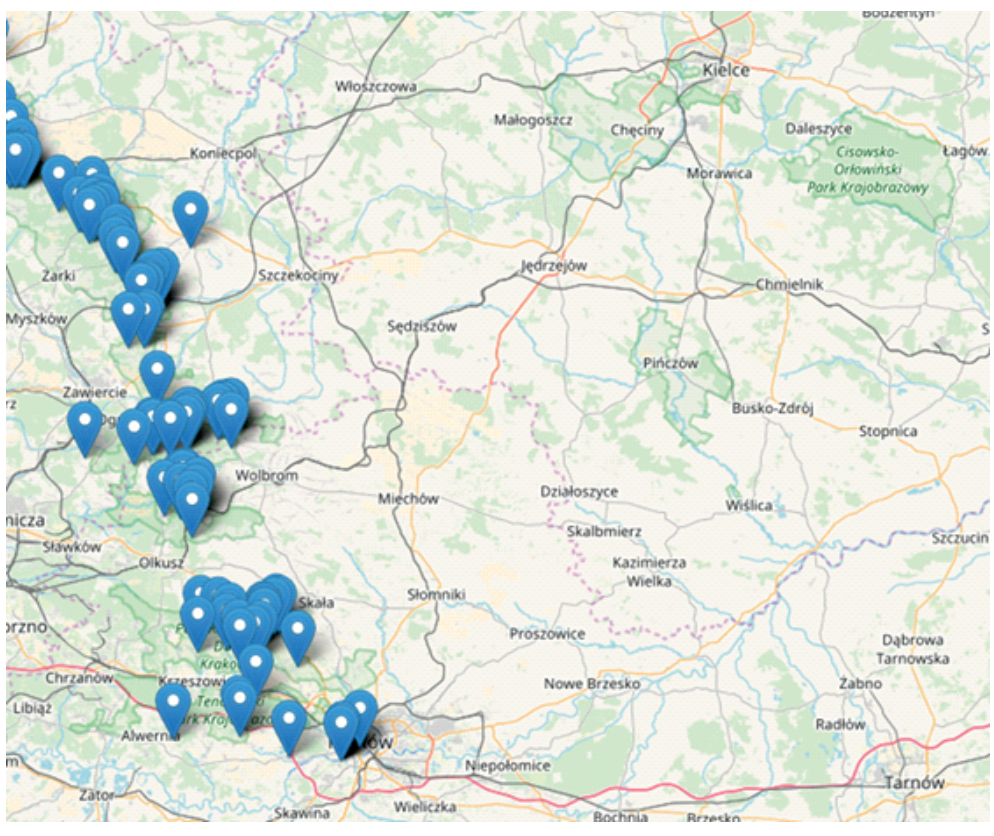

Rys. 10. Położenie jaskiń na obszarze Wyżyny KrakowskoCzęstochowskiej według portalu Jaskinie Jury (www.jaskinie jury.pl)

Fig. 10. The location of the karst caves in Krakow-Częstochowa Upland, according to portal (www.jaskinie jury.pl) 
Tabela 3. Wybrane parametry przestrzenne przykładowych jaskiń zlokalizowanych na obszarze Jury Krakowsko-Częstochowskiej

Table 3. Selected spatial parameters of exemplary caves located in the area of the Kraków-Częstochowa Upland

\begin{tabular}{|c|c|c|c|c|}
\hline \multirow[t]{2}{*}{ Nazwa jaskini } & $\begin{array}{c}\text { Dlugość } \\
\text { pojedynczych } \\
\text { korytarzy }\end{array}$ & $\begin{array}{l}\text { Szerokość } \\
\text { korytarzy }\end{array}$ & $\begin{array}{l}\text { Wielkość największych } \\
\text { komór krasowych } \\
\text { dl. } \times \text { szer. } \times \text { wys./obj. }\end{array}$ & \multirow[t]{2}{*}{$\begin{array}{l}\text { Główne kierunki przebiegu } \\
\text { korytarzy, komór i jaskiń }\end{array}$} \\
\hline & [m] & {$[\mathrm{m}]$} & {$\left[\mathbf{m} / \mathbf{m}^{3}\right]$} & \\
\hline Jaskinia Wierzchowska Górna & do 60 & do 5 & $40 \times 4-10 \times 3 / 840$ & NW-SE i SW-NE \\
\hline Jaskinia Nietoperzowa & do 10 & do $1-2$ & $6 \times 5 \times 10 / 300$ & SW-NE, pewne odcinki na SW-NE \\
\hline Jaskinia Łokietka & do 60 & do $5-6$ & $30 \times 20 \times 6-8 / 4200$ & SW-NE i NW-SE \\
\hline Jaskinia Studnisko & do $20-30$ & do $2-3$ & $18 \times 22 \times 10 / 396$ & SW-NE \\
\hline Jaskinia Smocza Jama & do 100 & do $3-4$ & $25 \times 10 \times 10 / 2500$ & SW-NE i NW-SE \\
\hline Jaskinia Kryspinowska & do $10-15$ & do $1-3$ & $10 \times 5 \times 5 / 250$ & SW-NE i NW-SE oraz N-S \\
\hline Jaskinia Zbójecka & do $130-150$ & do $2-4$ & $5 \times 5 \times 5 / 125$ & WSW-ENE \\
\hline Jaskinia Racławicka & do 15 & do $2-5$ & $30 \times 20 \times 5 / 3000$ & komora owalna, lok. kier. NW-SE i SW-NE \\
\hline Jaskinia nad Źródłem & do 40 & do 29 & brak komór & W-E i N-S oraz NW-SE \\
\hline Jaskinia Pychowicka & do 10 & do $2-3$ & $6 \times 4 \times 3,5 / 84$ & NW-SE i SW-NE \\
\hline Jaskinia Mamutowa & do 10 & do $1-4$ & $30 \times 15 \times 10 / 4500$ & SW-NE i NW-SE \\
\hline
\end{tabular}

$\mathrm{Na}$ świecie znane są znacznie większe obiekty, o olbrzymich pojemnościach, np. komora Sarawak Chamber w systemie jaskiniowym Lubang Nasib Bagus na Borneo ma wymiary $750 \times 400 \times 80$ do $100 \mathrm{~m}$, a jej pojemność wynosi $9,579 \mathrm{mln} \mathrm{m}^{3}$. Drugie miejsce zajmuje komora Salle des Miaos w systemie de la Gebihe w Chinach, o wymiarach $700 \times 215 \times 70$ do $100 \mathrm{~m}$, która razem $\mathrm{z}$ całym systemem jaskiniowym ma pojemność około $10,57 \mathrm{mln} \mathrm{m}^{3}$.

W Europie największą komorą jaskiniową jest La Grand Sala del GEV w jaskini La Torca del Carlista w Hiszpanii, o wymiarach $500 \times 230 \times 125 \mathrm{~m}$, której objętość szacuje się na 2,14 $\mathrm{mln} \mathrm{m}^{3}$. Drugą w Europie komorą jest Salle de la Verna w systemie jaskiniowym Pierre Saint-Martin we Francji, o wymiarach $255 \times 245 \times 180 \mathrm{~m}$, której pojemność wraz z całym systemem jest oceniana na $3,65 \mathrm{mln}^{3}$.

\section{Podsumowanie}

Przeprowadzone badania analityczne wykazały w rejonie Swarzów-Smęgorzów-Dąbrowa Tarnowska obecność różnych form paleokrasu w wapiennych utworach górnej jury. Mogą to być jaskinie, korytarze, studnie i leje krasowe itp. Struktury te występują zarówno w strefach złożowych, jak i poza nimi. W strefach złożowych struktury te są wypełnione węglowodorami, więc ich objętość stanowi część zasobów geologicznych i wydobywalnych złoża. Ten fakt był do tej pory nieuwzględniany, gdyż struktur krasowych wielkoskalowych dotychczas nie opisywano na złożach. Często zachodził inny przypadek, mianowicie że wyliczono wysokie zasoby dla złóż typu jurajskiego, a tymczasem wydobycie końcowe było na niskim poziomie, co składano na karb źle policzonych zasobów. Tymczasem może to wynikać z faktu, że część zasobów występujących w strefie krasu ze względu na duże komplikacje systemów krasowych jest łatwo odcinana podczas eksploatacji od pozostałej części złoża i w ten sposób staje się niewydobywalna.

Udokumentowanie struktur krasowych w złożach jurajskich prowadzi do wniosku, że w tych złożach pozostają jeszcze niewydobyte zasoby, pozostawione w tego typu strukturach, gdyż w większości były one dotychczas nieudostępnione odwiertami. Obecność paleokrasu prowadzi też do zmiany modelu geologiczno-złożowego złóż jurajskich i o mieszanej litologii. W nowym modelu skały jurajskie będą miały zdecydowanie większe znaczenie niż dotychczas, dlatego też będzie musiał zmienić się sposób rozwiercania i udostępniania tego typu złóż.

\section{Wnioski}

1. Przeprowadzona analiza rdzeni otworów wiertniczych w rejonie Swarzów-Smęgorzów-Dąbrowa Tarnowska wykazała obecność form paleokrasu, powstałego przypuszczalnie w dolnej kredzie i paleogenie, w utworach wapiennych górnej jury.

2. Zidentyfikowane formy krasowe to zarówno małe kawerny, kanaliki, szczeliny rozszerzone przez procesy krasowe, jak i większe formy krasowe, mogące reprezentować: studnie i leje krasowe, jaskinie, korytarze, duże kawerny itp.

3. Kopalne formy paleokrasu wykazują częściowe lub całkowite wypełnienie osadami z okresu formowania się krasu - są to osady rezydualne, iły, zlepieńce, oraz osady napływowe, jak np.: iły, muły, piaskowce, zlepieńce, zlepy 
muszlowe; wolne od osadów przestrzenie krasu w strefie złożowej mogą być wypełnione przez węglowodory.

4. W utworach wapiennych górnej jury udokumentowanie obecności paleokrasu otwiera nowe możliwości poszukiwawcze w rejonie zapadliska przedkarpackiego w zakresie odkrycia nowych złóż, jak i reinterpretacji zasobów złóż dotychczas eksploatowanych.

Artykuł powstał na podstawie pracy statutowej pt.: Uwarunkowania geologiczne podłoża podmioceńskiego $w$ procesie formowania się złóż węglowodorów na obszarze zapadliska przedkarpackiego - praca INiG - PIB na zlecenie MNiSW; nr zlecenia: 215/0008/18/01, nr archiwalny: DK-4100-8/2018.

\section{Literatura}

Barbacki A.P., 2002. Geotermalny basen górnej jury centralnej części zapadliska przedkarpackiego i południowo-wschodniej części niecki miechowskiej - budowa geologiczna i warunki hydrogeotermalne. Przeglad Geologiczny, 50(9): 773-782.

Barbacki A.P., Kazanowska A., 2001. Środkowojurajska formacja geotermalna centralnej części zapadliska przedkarpackiego i obszarów przyległych. Przegląd Geologiczny, 49(10/1): 894-900.

Bardziński W., Kurowska E., 2017. Kras kopalny w podłożu Autostrady A1 w rejonie Częstochowy. W: Materiały 51. Sympozjum Speleologicznego (s. 40). Kraków: Sekcja Speleologiczna Polskiego Towarzystwa Przyrodników im. Kopernika.

Black T.J., 2012. Deep karst system research, Michigan, USA. Carbonates and Evaporites, 27: 119-122.

Cao J., Tang Z., Zhang Q., Dan Y., 2017. Paleogeomorphic genesis assembly method for paleogeomorphic recovery in the major region of the Tahe Oil Field, Tarim Basin, northwest China. Carbonates and Evaporites. DOI: 10.1007/s13146-017-0380-3.

Dai X., Zhang M., Jiang Q., Feng Z., 2017. Karst reservoirs seismic prediction of Lower Permian Maokou Formation in central Sichuan Basin, SW China. Petrol. Explor. Develop., 44(1): 79-88.

Dudek J., 1980. Warunki geologiczno-strukturalne pułapek i parametry złożowe górnej jury w zapadlisku przedkarpackim. Prace IGNiG nr 37. Kraków: IGNiG.

Felisiak I., 2016. Fossil karst in the Jurassic of the Kościuszko Mound in Kraków (southern Poland): discussion. Geological Quarterly, 60(1): 252-255.

Gao D., Lin Ch., Hu M., Haijun Yang H., Lili Huang L., 2018. Paleokarst of the Lianglitage Formation related to tectonic unconformity at the top of the Ordovician in the eastern Tazhong Uplift, Tarim Basin, NW China. Geological Journal, 53: 458-474.

Gradziński M., 1995. Zjawiska krasowe, powstawanie jaskiń, osady jaskiniowe. Jaskinie, 4: 21-25.

Gradziński M., Gradziński R., Jach R., 2008. Geologia, rzeźba i zjawiska krasowe okolic Ojcowa. W: A. Klasa, J. Partyka (red.), Monografia Ojcowskiego Parku Narodowego. Przyroda. Ojców: Ojcowski Park Narodowy.

Gradziński R., 1962. Rozwój podziemnych form krasowych w południowej części Wyżyny Krakowskiej. Rocznik Polskiego Towarzystwa Geologicznego, 32: 429-492.

Gutowski J., Urbaniec A., Złonkiewicz Z., Bobrek L., Świetlik B., Gliniak P., 2007. Stratygrafia górnej jury i dolnej kredy środkowej części przedpola polskich Karpat. Biuletyn Państwowego Instytutu Geologicznego, 426: 1-26.

Jiang Z., Huang S., Du H., Li Y., Wang B., Cao Y., Zhang Y., 2015. The characteristics of the neotectonic movement and their effects on the formation of gas reservoirs in the marginal depressions of Tarimbasin, NW China. Journal of Natural Gas Science and Engineering, 22: 503-514.

Katalog wierceń górnictwa naftowego w Polsce, 1970. T. 1, cz. 3 i 4. Warszawa: Wydawnictwa Geologiczne.

Lin Ch., Yang H., Liu J., Rui Z., Cai Z., Li S., Yu B., 2012. Sequence architecture and depositional evolution of the Ordovician carbonate platform margins in the Tarim Basin and its response to tectonism and sea-level change. Basin Research, 24: 559-582.

Miziołek M., Filar B., Cierzniak M., 2017. Pułapki złożowe zapadliska przedkarpackiego w czołowej strefie nasunięcia Karpat. Nafta-Gaz, 8: 551-557. DOI: 10.18668/NG.2017.08.02.

Oszczypko N., 2006. Powstanie i rozwój polskiej części zapadliska przedkarpackiego. Przeglad Geologiczny, 54: 396-403.

Oszczypko N., Tomaś A., 1978. Charakterystyka własności zbiornikowych osadów jurajskich na przedgórzu Karpat środkowych. Kwartalnik Geologiczny, 22(3): 585-600.

Radwański A., 1968. Transgresja dolnego tortonu na obszarze Wyżyny Miechowskiej i Krakowskiej. Acta Geologica Polonica, 18: 387-445.

Russell W.H., 2007. Stratigraphic Distribution of Cave Volume in the Edwards Limestone, Southern Travis county, Texas. Texas Speleological Survey. Austin Geological Society Bulletin, 3: 37-42.

Sun S., Zhao W., Zhang B., Liu J., Zhang J., Shan X., 2013. Observation and implication of the paleo-cave sediments in Ordovician strata of Well Lundong-1 in the Tarim Basin. Science China Earth Sciences, 56(4): 618-627.

Szulc J., Worobiec E., Ziaja J., 2015. Polifazowy kras kopalny Wyżyny Śląsko-Krakowskiej. W: Materiały 49. Sympozjum Speleologicznego (s. 118). Kraków: Sekcja Speleologiczna Polskiego Towarzystwa Przyrodników im. Kopernika.

Tian F., Lu X., Zheng S., Zhang H., Rong Y., Yang D., Liu N., 2017. Structure and Filling Characteristics of Paleokarst Reservoirs in the Northern Tarim Basin, Revealed by Outcrop, Core and Borehole Images. Open Geosci., 9: 266-280.

Urban J., Rzońca B., 2009. Karst systems analyzed using borehole logs - Devonian carbonates of the Świętokrzyskie (Holy Cross) Mountains, central Poland. Geomorphology, 112(1/2): 27-47.

Urbaniec A., 2017. Nowe spojrzenie na budowę geologiczną brzeżnej części Karpat i ich podłoża (SE Polska) w oparciu o interpretację profili sejsmicznych. Wiadomości Naftowe i Gazownicze, 20(2): 4-12.

Wódka M., Wójcik A., 2016. Historia geologiczna Wzgórza Świętej Bronisławy. 6. Formy, osady i zjawiska krasowe. W: A. Wójcik (red.), Kopiec Kościuszki i jego podłoże geologiczne. Atlas - przewodnik (s. 61-73). Kraków: Urząd Miasta Krakowa.

Wójcik A., Garecka M., Olszewska B., Wódka M., 2015. Fossil karst in the Jurassic of the Kościuszko Mound in Kraków (southern Poland). Geological Quarterly, 59(1): 61-70.

Zhang B., Liu J., 2009. Classification and characteristics of karst reservoirs in China and related theories. Petrol. Explor. Develop., 36(1): 12-29.

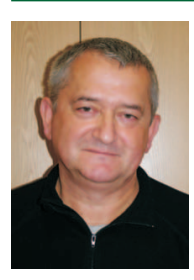

Mgr Mariusz MIZIOŁEK

Starszy specjalista badawczo-techniczny w Zakładzie Podziemnego Magazynowania Gazu

Instytut Nafty i Gazu - Państwowy Instytut Badawczy ul. Lubicz 25 A

31-503 Kraków

E-mail: mariusz.miziolek@inig.pl

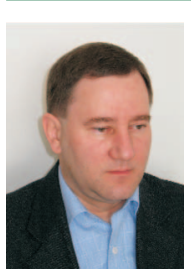

Mgr inż. Bogdan FILAR

Starszy specjalista badawczo-techniczny; kierownik Zakładu Podziemnego Magazynowania Gazu Instytut Nafty i Gazu - Państwowy Instytut Badawczy ul. Lubicz 25 A

31-503 Kraków

E-mail: bogdan.filar@inig.pl 